\title{
Improving Access to Diabetes Care for Children: An Evaluation of the Changing Diabetes in Children project in Kenya and Bangladesh
}

\author{
Improving Access to Diabetes Care for Children \\ Tom Palmer ${ }^{1}$, Hannah Maria Jennings ${ }^{2}$, Geordan Shannon ${ }^{1}$, Francesco Salustri ${ }^{1}$, \\ Gulraj Grewal ${ }^{3}$, Winnie Chelagat ${ }^{3}$, Mithun Sarker ${ }^{4}$, Nicole Pelletier ${ }^{1}$, Hassan \\ Haghparast-Bidgoli ${ }^{1}$, Jolene Skordis ${ }^{1}$ \\ ${ }^{1}$ Institute for Global Health, University College London, London, United Kingdom \\ ${ }^{2}$ Department of Health Sciences, University of York, York, United Kingdom \\ ${ }^{3}$ Global Health Disrupted, Nairobi, Kenya \\ ${ }^{4}$ Diabetic Association of Bangladesh, Dhaka, Bangladesh
}

\section{Acknowledgements}

UCL was funded by Novo-Nordisk to provide an independent review of the CDiC program in Kenya and Bangladesh. Novo-Nordisk signed a binding a-priori agreement confirming that the company would have no input into the design of the study or the analysis of the findings. Novo-Nordisk have not contributed to the writing of this paper, the interpretation of the data or the conclusions reached

\section{Author Contributions}

T.P., H.M.J., G.S., H.H.B and J.S designed the study. T.P., H.M.J., G.G., W.C. and M.S. performed the research. T.P., H.M.J, G.G. and N.P. analysed the data. T.P., H.J.M, F.S. and G.S. wrote the paper. All authors have read and approved the final manuscript.

This article has been accepted for publication and undergone full peer review but has not been through the copyediting, typesetting, pagination and proofreading process which may lead to differences between this version and the Version of Record. Please cite this article as doi: 10.1111/pedi.13277 


\begin{abstract}
Background

The Changing Diabetes in Children (CDiC) project is a public-private partnership implemented by Novo Nordisk, to improve access to diabetes care for children with Type 1 Diabetes. This paper outlines the findings from an evaluation of CDIC in Bangladesh and Kenya, assessing whether CDiC has achieved its objectives in each of six core program components.

\section{Methods}

The Rapid Assessment Protocol for Insulin Access (RAPIA) framework was used to analyse the path of insulin provision and the healthcare infrastructure in place for diagnosis and treatment of diabetes. The RAPIA facilitates a mixed-methods approach to multiple levels of data collection and systems analysis. Information is collected through questionnaires, in-depth interviews and focus group discussions, site visits and document reviews, engaging a wide range of stakeholders $(\mathrm{N}=127)$. All transcripts were analysed thematically.

\section{Results}

The CDiC scheme provides a stable supply of free insulin to children in implementing facilities in Kenya and Bangladesh, and offers a comprehensive package of paediatric diabetes care. However, some elements of the CDiC program were not functioning as originally intended. Transitions away from donor funding and towards government ownership are a particular concern, as patients may incur additional treatment costs, while services offered may be reduced. Additionally, despite subsidised treatment costs, indirect costs remain a substantial barrier to care.

\section{Conclusion}

Public-private partnerships such as the $\mathrm{CDiC}$ program can improve access to life-saving medicines. However, our analysis found several limitations, including concerns over the sustainability of the project in both countries. Any program reliant on external funding and delivered in a high-turnover staffing environment will be vulnerable to sustainability concerns.
\end{abstract}

Keywords: type 1 diabetes, child, delivery of health care, low- and middle-income countries, public-private sector partnerships 


\section{Introduction}

In 2019, an estimated 1.1 million children and adolescents (aged 0-19 years) had Type 1 Diabetes (T1DM) globally. Of these, approximately 25,000 lived in Africa and 184,000 lived in South-East Asia. ${ }^{1}$ Of the 130,000 children and adolescents newly diagnosed globally each year, around 10,000 are in Africa and 21,000 are in South-East Asia. ${ }^{1}$ In Kenya and Bangladesh, the number of children living with Diabetes is currently unknown. Although figures in the International Diabetes Federation Atlas suggest 1,694 children and adolescents in Kenya and 5,350 in Bangladesh have T1DM ${ }^{1}$, the true figures remain uncertain given that the majority of cases will never be diagnosed, and relevant data remain scarce in many low- and middle-income countries (LMICs). For example, in Africa, the proportion of people with undiagnosed Diabetes (Type 1 and Type 2) is estimated at 59.7\%. ${ }^{1}$ The seemingly low incidence and prevalence of T1DM amongst children may underestimate the true burden of the disease, given the high case fatality rate suggested by existing evidence in these settings. ${ }^{2-4}$

Although disease control is possible with appropriate management, children with T1DM report lower health-related quality of life, in part due to the burden of complex and invasive practices required to maintain glycaemic control. ${ }^{5}$ The importance of good glycaemic control in reducing the risk of complications, including retinopathy, nephropathy, and neuropathy, has been firmly established. ${ }^{6}$ However, in many LMIC settings, even amongst children who are diagnosed, many families still lack access to the key components of glycaemic control management, including uninterrupted insulin supply, access to blood glucose testing and appropriate education and support.

To address these challenges, the Changing Diabetes in Children (CDiC) program was established and implemented by Novo Nordisk as a private-public partnership, aiming to improve access to Diabetes care for children with T1DM in LMICs. The CDiC program launched in 2009 and is currently running in fourteen countries in Africa and Asia and children aged 18 years old or younger are eligible for enrolment. In each country, the $\mathrm{CDiC}$ program works local partners, including the Kenyan Ministry of Health in Kenya and the Diabetic Association of Bangladesh, to build capacity and strengthen capability within the existing healthcare system. There are six core components of the CDiC program: improvement of existing infrastructure; training and education of healthcare professionals; provision of insulin and blood glucose monitoring equipment; provision of patient education material; patient registry system and effective data management; and best practice sharing.

Two existing studies have looked at biomedical outcomes amongst children enrolled in the the CDiC program in Cameroon. ${ }^{7,8}$ One is a longitudinal study, measuring outcomes at enrolment in the CDiC program and one year later. ${ }^{7}$ The authors find a significant improvement in glycaemic control, suggesting a reduction in mean HbA1c in the year following enrolment $(11.4 \% \pm 2.7 \%$ vs $8.7 \pm 2.4 \%)$. The second is a cross-sectional study of $\mathrm{CDiC}$ patients. ${ }^{8}$ The mean $\mathrm{HbAlc}$ amongst participants was $9.2 \%( \pm 2.5 \%)$, the authors suggesting that only $32.6 \%$ of patients had good glycaemic control, though the levels used for this categorisation remain unclear. Poor glycaemic control remains a challenge across different settings. Estimates from a longitudinal analysis in 2011 in Bangladesh suggest that, amongst 2-17 year olds, mean $\mathrm{HbAlc}$ was reduced in in the year following $\mathrm{CDiC}$ enrolment, but remained at a high level $(10.8 \% \pm 2.8 \%$ vs $10.0 \% \pm 2.4 \%) .{ }^{9}$ A study in Kenya, not related to $\mathrm{CDiC}$, found that amongst adolescents aged 12 years and above, only $4 \%$ had reasonable glycaemic control, defined by measured $\mathrm{HbAlc}$ of $8 \%$ or less. ${ }^{10} \mathrm{~A}$ further study in the US found that only $32.4 \%$ of $13-18$ year olds had good glycaemic control, defined by measured $\mathrm{HbA} 1 \mathrm{c}$ of $7.5 \%$ or less. ${ }^{11}$ These challenges reflect the need for a comprehensive package of care beyond provision of insulin, in line with International Society for Pediatric and Adolescent Diabetes (ISPAD) guidelines which emphasise the importance of multidisciplinary care. ${ }^{12}$ However, the broader CDiC program was not evaluated in either of the Cameroon studies. 
This paper aims to provide a situational analysis of diabetes care for children in Kenya and Bangladesh, in order to inform policymaking and support the improvement of healthcare interventions. This objective was addressed in the context of an evaluation of the T1DM care for children provided through the $\mathrm{CDiC}$ program in Bangladesh and Kenya. We assessed whether CDiC affected paediatric T1DM care in each setting, when compared with existing care. Through qualitative semi-structured interviews, questionnaires and site visits, the evaluation analyses how the CDiC program was implemented in each setting and how it has evolved. Then, we assess the CDiC program in terms of each of the six components of the program and discuss the sustainability of the CDiC in Kenya and Bangladesh.

\section{Methods}

\section{Study Setting}

In Kenya, the $\mathrm{CDiC}$ project began in 2012 and has been implemented using a "hub-and-spoke" model, with 12 hubs and 14 spokes distributed across the country. The 'hubs' are the main clinics (typically county-level referral hospitals) and serve as referral clinics. The 'spokes' are smaller clinics (typically sub-county hospitals), which aim to reduce travel distance to facilities for patients. Implementing facilities were chosen based on the geography and available healthcare infrastructure of Kenya. The Ministry of Health manages 11 of the main 'hubs', while the Kenya Diabetes Management and Information Centre (DMI) runs a separate unit in Nairobi. Of the 14 'spokes', one (Tenwek Mission Hospital) is run by the Christian Health Association of Kenya, while the remaining facilities are all run by the Ministry of Health. Given the large number of CDiC implementing facilities in Kenya, three main 'hubs' were selected in a purposive manner from the total number of facilities for full evaluation. These facilities were considered to be broadly representative of Kenya nationally in terms of sociodemographic characteristics. These were Kisii County Referral Hospital, Kericho County Referral Hospital and Ngaira Dispensary in Nairobi. Additionally, a more limited collection of data took place in three further implementing facilities: Embu County Referral Hospital, Chuka Referral Hospital and Nakuru County Referral Hospital. Finally, full data collection took place in one non-implementing facility: Kitale County Referral Hospital. For a full summary of the methods used in each facility, see Appendix Table A2.

Outside of the CDiC program, most children with T1DM pay for their insulin, either at Ministry of Health facilities or private facilities. In the public sector, specialised diabetes clinics provide care for both adults and children within sub-county, county and national referral hospitals. There are also other private-public partnerships operating within Ministry of Health facilities throughout various regions of Kenya. For example, the Life for a Child (LFAC) program, using insulin supplied by Eli Lilly, operates only from Kenyatta National Hospital in Nairobi. A further example of private sector involvement in diabetes care delivery in Kenya is that Safaricom, a mobile network operator, announced plans in 2019 to fund diabetes clinics for children in Garissa County.

In Bangladesh, the CDiC project began in 2009, in collaboration with the World Diabetes Foundation (also founded by Novo Nordisk) and the Diabetic Association of Bangladesh (BADAS). There are three implementing facilities in Bangladesh: one large specialised multidisciplinary clinic in Dhaka and two smaller clinics in Chittagong and Faridpur. All the clinics are located within BADAS hospital buildings. Data were collected from all three implementing facilities during this study. Another large program offering free T1DM treatment, Life for a Child, operates in 58 of 64 districts in Bangladesh, including sending insulin to peripheral areas. ${ }^{13}$ A recent article suggests that both Life for a Child and $\mathrm{CDiC}$ have around 3,000 enrolled children each in Bangladesh, treating the majority of an estimated 9,000 children with diabetes nationally. ${ }^{14}$ The remaining children are likely to pay for their own treatment.

\section{Analytical framework}


In order to evaluate both the $\mathrm{CDiC}$ and paediatric care for T1DM more generally in both countries, we adapted the Rapid Assessment Protocol for Insulin Access (RAPIA). ${ }^{15}$ Originally used in Zambia, Mozambique and Mali, the RAPIA approach was also implemented in Kenya in 2016 as part of Novo Nordisk's Base of the Pyramid program evaluation. ${ }^{16}$ The RAPIA framework analyses the path of insulin and the healthcare infrastructure in place for diagnosis and treatment of diabetes, identifying barriers to effective care at different levels of the health system. The RAPIA facilitates a mixed-methods approach to multiple levels of data collection and systems/process analysis. Information is collected through questionnaires, in depth discussions, site visits, and document reviews, engaging a wide range of stakeholders. This approach also facilitates comparisons between different settings. For a detailed outline of the adapted RAPIA approach see Table A1 in Appendix.

To facilitate comparisons between facilities with and without the $\mathrm{CDiC}$ program and enable conclusions on the extent to which differences in responses can be attributed to CDiC activities, we purposively selected one 'control' facility at which $\mathrm{CDiC}$ has not been implemented in each country. Selected control facilities served a nationally representative area and were crudely matched to the 'intervention' facilities in terms of socio-demographic and health characteristics of patients. Table 1 summarises the facility and county-level characteristics of each included facility in each country.

Table 1

\section{Data collection and analysis}

We utilised the RAPIA multi-level structure to gather information on the six core components of the $\mathrm{CDiC}$ program. More specifically, we collected information through qualitative semi-structured interviews and focus group discussions with stakeholders at the Micro, Meso, and Macro health system levels. ${ }^{15}$ Macro-level information represents the national and international level structure of healthcare services, such as government ministries, national organisations, and other centralised services. The Macro level interviews established the international infrastructure around Diabetes care led by the program funder (i.e., Novo Nordisk), the synergies and shared values between partners, and the sustainability of the program. Meso-level information is derived from interviews with county health authorities, and Micro-level information is collected from individual patients, carers, and service providers. The Meso and Micro level interviews explored the impact of the program on patient care and clinical outcomes, barriers to Diabetes care for children, and the sustainability of the program. At the Micro level, children and carers participated in separate focus group discussions. Where appropriate, focus group discussions with young children also included participatory activities such as ranking exercises and using visual aids. Some families were also provided with mobile phones to enable photo-diary data collection. Photo-diary methods were used to gain an understanding of the children's lived experience of T1DM and are the focus of an additional paper ${ }^{17}$

Table 2 details the number of participants at each level of data collection in each country. A total of 50 individuals participated in the study in Kenya, including 4 focus group discussions with children, 3 focus group discussions with carers and a further 19 semi-structured interviews with adult participants across Micro, Meso and Macro levels. In Bangladesh, 77 individuals participated in the study, including 10 focus group discussions with children, 1 small group interview with a caregiver and her teenage child, and a further 24 semi-structured interviews with adult participants across Micro, Meso and Macro levels. A further 2 individuals from international organisations participated to provide overall insight into care for children with T1DM globally.

To provide a balanced evaluation of health care services, we also combined the interviews with questionnaires, site visits, and document reviews. Where possible and appropriate, data from the qualitative key informant interviews was supplemented with available secondary quantitative and qualitative data. These secondary data were collected through structured survey tools developed in conjunction with local partners. For a summary of the different data collected at each facility, see Table A2 in Appendix. 
Two separate teams consisting of a trained interviewer, paired with an experienced translator and notetaker, conducted all field interviews in each country. After obtaining consent, all interviews were audio recorded and detailed interview notes taken. Fieldwork was conducted in either English or Swahili in Kenya, and in Bangla in Bangladesh. Data collection took place between March and April 2019 in Kenya, and between April and July 2019 in Bangladesh. In both countries, data collection and analysis took place simultaneously and an initial analysis of each interview was made before the next interview. Interviews were transcribed verbatim directly into English by a team of experienced transcribers. In both countries, a sample of random 5-minute segments were back-translated in order to check for the quality of the translation. No substantive differences were found in the translations. All transcripts were analysed thematically in an inductive manner. In each country both researchers independently coded transcripts and generated initial themes, before meeting to review and finalise these themes. Data were analysed either manually or using NVivo.

\section{Research access and ethics}

For local expertise and research support, UCL partnered in Kenya with Global Health Disrupted, a nongovernment organisation, and in Bangladesh with Perinatal Care Project, a research organisation that is part of BADAS. The program funder (Novo Nordisk) was not involved in the design or implementation of the study, did not have access to any primary data collected and were only presented with study results after the study had concluded. Ethical approval was granted by the University College London Research Ethics Committee (14657/001). Local ethical approval was granted by the Amref Ethics and Scientific Review Committee in Kenya (P588/2019), and by the Ethics Committee of the Bangladesh Diabetic Association (19/00273).

All participants gave written consent for participating in the study, including the use of audio recordings. All participating children were recruited through diabetes clinics and gave assent to participate, including on the use of photo-diary methods. Written consent was obtained from their caregivers.

Table 2

\section{Results}

In this section we summarise the results of the evaluation by each of the six core components of the CDiC program.

\section{Improvement of existing infrastructure}

For the purposes of this evaluation, infrastructure was defined as long-term meso- or macro-level investments in buildings, medical equipment, communication systems and ambulatory systems. Although infrastructure may have been a significant part of the $\mathrm{CDiC}$ program in other countries, large infrastructure projects were not identified by respondents as a key component of the project in Kenya and Bangladesh. In Bangladesh, CDiC clinics in Dhaka were located within the large infrastructure of BIRDEM General Hospital. In Kenya, CDiC clinics were similarly held in existing healthcare facilities. Although there have been improvements in forecasting and supply of insulin and other goods under the scheme, this did not appear to have improved existing infrastructure. The scheme bypassed national infrastructure for supply of insulin and equipment. Insulin was distributed by a third party (Phillips), rather than using or improving the government supply agency, the Kenya Medical Supplies Authority (KEMSA). Although glucose monitoring supplies previously went through KEMSA, they were now also going through a third party, the Red Cross, in order to reduce costs.

Similarly, in Bangladesh, $\mathrm{CDiC}$ clinics were also held within existing healthcare facilities. In Dhaka, a new clinic with nine rooms was established in 2012 within BADAS's second flagship hospital building (BIRDEM-2, dedicated to the care of women and children). Physical infrastructure across the 
three CDiC centres differed significantly. The Chittagong and Faridpur clinics, also located within existing Diabetic hospitals, are much smaller facilities where, while able to store insulin, they rely heavily on their host hospitals for support services, such as labs. In these two facilities, communication and ambulatory systems for referral linkage were also limited and relied on the host hospitals for transportation. There was also a reported need for additional investment in basic equipment and infrastructure in these two facilities.

\section{Training and education of healthcare professionals}

At the micro level, healthcare workers often lacked diabetes experience and considered T1DM a challenging disease to treat, given serious complications such as diabetic ketoacidosis. In Kenya, CDiC had trained over 200 health care workers in diabetes care specifically for children, whereas previously children were treated with protocols designed for adults by staff who more frequently treat adults with Type 2 Diabetes (T2DM). Staff reported that their diagnostic competency had increased, and they could now more easily rule out more common infectious diseases. However, in many cases training had last been offered several years before this study and staff turnover in many facilities is high. In the control facility, despite recent mentoring of clinicians on diabetes, one health care worker expressed that they did not feel they have the skills to treat children, as they had not been trained in paediatric care, and relied on resources such as books and online videos. Additionally, although such training is an important capacity building exercise, given the high staff turnover in Kenya, and given the low number of beneficiaries on a national scale, this cannot be considered as an improvement in long-term capacity.

Meso- and macro-level stakeholders in Bangladesh claimed that training for T1DM is inadequate and, similar to Kenya, children were generally treated by practitioners more familiar with older T2DM patients. It was reported by Novo Nordisk that $\mathrm{CDiC}$ have trained a number of doctors from all sectors (government, private and $\mathrm{NGO} /$ charity sector), though these were mostly one-off trainings. One health care professional suggested that the number of people trained has declined over time, and that as training was not repeated staff were not up to date with the latest practices in T1DM treatment. Staff working at $\mathrm{CDiC}$ facilities reported that they follow International Society of Paediatric and Adolescent Diabetes guidelines for care, and felt their patients were receiving international standards of care. However, in contrast to Kenya, staff at the control facility also reported receiving training organised by CDiC. In both countries, stakeholders suggested that training should be held more regularly. Additionally, both countries trained multidisciplinary teams of staff including doctors, nurses, clinical officers, pharmacists, nutritionists, psychologists, social workers and others.

\section{Provision of insulin and blood glucose monitoring equipment}

In both countries, the $\mathrm{CDiC}$ program appeared to provide a dependable supply of free insulin to children in implementing facilities. In Kenya, children typically received Mixtard vials, though there was also some availability of Actrapid. Although no issues were reported at implementing facilities, at the control facility at the time of data collection there had been no insulin in the hospital for three months. Staff at the control hospital in Kenya reported cases of severe adverse events and death due to a lack of insulin. Staff also reported "competition" for the limited insulin supplies when they are in stock, such that adults with Type 2 diabetes often purchased most of the supplies when they arrive, leaving little for children with T1DM. Outside of $\mathrm{CDiC}$ implementing facilities, affordability frequently prohibited children's access to insulin. When available, the control facility in Kenya provided insulin (procured from Academic Model Providing Access to Healthcare; AMPATH) to children for $200 \mathrm{KES}(\sim 2)$ per vial. Particularly for those on higher doses, this subsidised price is still unaffordable for many families. In the open market, insulin can cost up to $800-1000 \mathrm{KES}(\sim \$ 8-10)$ per vial. However, at the time of data collection, even private chemists in this area did not have any insulin stock. Although a $200 \mathrm{KES}$ per vial price was previously mandated under a 2007 government directive (i.e. insulin was subsidised), following devolution the price has increased and public health facilities nationally may now charge between 200-500 KES per vial of insulin. 
In Bangladesh, at the meso-level, there were no reported shortages of insulin in CDiC facilities, and the control facility also had available insulin stock. Children typically received Actrapid and Insulatard vials. In the Dhaka clinic, one health educator interviewed suggested that there were issues with the insulin supply from Novo Nordisk at times, resulting in insulin arriving late at the clinic. The frequency of such incidents is unclear based on collected data.

The Government of Bangladesh introduced a price cap for insulin which is strictly adhered to, resulting in a relatively stable price of insulin over the last five years of around 400 Bangladeshi taka (BDT; $\sim$ 5) per vial. In Bangladesh, Novo Nordisk has also campaigned with BADAS to have insulin listed as an 'essential medicine' in Bangladesh that must be free on point of delivery, which is not currently the case. The stakeholders interviewed were hopeful that this will happen in the next two years, although the outcome of these discussions is by no means guaranteed.

In both countries, there was incomplete provision of free supplies aside from insulin, including syringes, lancets, glucometers and glucose strips. Although previously provided through CDiC Kenya, children enrolled in the program now bought their own supplies. If not subsidised, many of these supplies were prohibitively expensive for families, particularly glucometers which cost around 5,000 Kenyan shillings (KES; $\sim 50$ ) in Kenya. The reasons for these changes to provision of supplies through the scheme were not always communicated consistently to facilities. In Kenya, one facility had been told that there was an acute national shortage of strips and syringes, while another facility was told that supply had stopped as the program was coming to an end and they were being "weaned" off the project. This resulted in worse disease management, such as patients using syringes many more times than is recommended. In Bangladesh, free supplies were not available to everyone enrolled in the program. For example, in Dhaka, a reported $700-800$ of the 2000 children and adolescents regularly attending CDiC clinics received glucometers and strips.

\section{Provision of patient education material}

Under the $\mathrm{CDiC}$ program, children were moved away from the adult diabetic population (who greatly outnumber children) and receive paediatric care. In Kenya, prior to the $\mathrm{CDiC}$ program, children were using adult educational materials that depicted adult bodies and were considered inappropriate. Parents and children on the $\mathrm{CDiC}$ scheme were well-informed on diabetes management and received education on a wide range of topics, including glucose monitoring, insulin use, insulin storage and foot care. Children were able to independently inject themselves at a very young age and were proud of their independence. ${ }^{17}$ All implementing facilities were supplied with posters and patient education booklets for children. However, beyond that, the delivery of education and level of psychosocial support available varied by facility. Although residential education camps were once part of the scheme, it appears that funding from Novo Nordisk for the camps has ceased. In their absence, camps were funded by Safaricom (with involvement of DMI) in both intervention and control counties. These camps were seen as extremely valuable because they provided a lot of education in a short time and made children feel part of a community.

In Bangladesh, $\mathrm{CDiC}$ facilities in Dhaka and Chittagong initially offered children and parents individual education sessions and later encouraged them to join in group sessions. By contrast, in the Faridpur $\mathrm{CDiC}$ clinic, there were no educators and children were instead provided with a guidebook on diabetes management. There was an 'insulin corner' with leaflets and dummies where children could practice injecting. All sites provided education material in Bangla to patients and parents. The control facility also did not have educators and had educational material for older patients only and children were often referred elsewhere.

\section{Patient registry system and effective data management}

Facilities often had very limited information and communications technology infrastructure, which creates challenges both for patient monitoring and for forecasting of supplies. There was still a strong 
reliance on paper records in both implementing and non-implementing facilities. In Kenya, although a $\mathrm{CDiC}$ registry was created for data entry, the $\mathrm{CDiC}$ program had not necessarily improved data management practices. There were no guidelines in place for data management and routinely collected outcomes were typically limited to diabetic ketoacidosis, deaths and loss to follow-up. Data entry and maintenance was an additional burden on already overstretched staff, and there appeared to be little incentive for staff to complete it. One implementing facility (a referral hospital) still relied entirely on paper-based systems to record patient outcomes. Another implementing facility reported that they tried to maintain digital records, but their computers often break, meaning the data can be lost.

In Bangladesh, the Dhaka $\mathrm{CDiC}$ clinic maintained digital records of registered patients, employing a staff member for data-entry. Although the clinic attempted to capture follow-up data to monitor attendance and test results, these were often recorded on paper and were not always entered digitally. In the smaller centres (Faridpur and Chittagong) all patient details and visits were recorded on paper. At the $\mathrm{CDiC}$ centres included in this study, there were records of the number of patients, admissions and tests for the last 12 months. This was in stark contrast to the control centre, where there were no regular records.

\section{Best practice sharing}

In Kenya, the CDiC program was well anchored within the Ministry of Health, who have taken ownership and were fully involved with implementation and working with the facilities. All national partners shared a strong sense of the value of the $\mathrm{CDiC}$ and were committed to providing a service they believed was an important and emotive issue, as it affects disadvantaged children. Stakeholders reported that an effective working relationship had been established between national project partners. In Bangladesh, CDiC was described by stakeholders be an example of excellent practice. Having a childfocused centre with a multi-disciplinary approach was felt to be particularly important. Respondents suggested that government and other healthcare providers in Bangladesh have been able to learn from the $\mathrm{CDiC}$ program, which is recognised nationally and internationally.

Despite this, communication was found to be an issue, particularly with respect to the end date of the program in each country. Concerns about program sustainability were raised by most study participants. In Kenya, staff at implementing facilities were often unclear about whether support for the $\mathrm{CDiC}$ program would continue. Facilities were left to speculate as to when the scheme would end amid conflicting messaging, often drawing erroneous conclusions. Similarly, in Bangladesh the uncertain future of $\mathrm{CDiC}$ was a serious concern for all facilities in the study. Health workers explained that after 2020 there were no known plans to extend the current funding. In both countries this suggested a lack of planning for a sustainable transition away from donor funding.

\section{Discussion}

Our analysis shows that the program established a stable supply of free insulin in implementing facilities to children living in Kenya and Bangladesh. Previously no other package of care was tailored specifically towards children with T1DM. In addition to the medical needs of the children, CDiC strives to educate and offer psychological support.

The scheme also has several weaknesses. For example, in Kenya pre-mixed insulin was typically used for children. ISPAD guidelines recommend that pre-mixed insulin should not be used, as there is some evidence of poorer metabolic control when used in adolescents ${ }^{18,19}$ In Kenya, Mixtard is widely used and is the main insulin product procured through KEMSA. One study found that Mixtard comprised $84 \%$ of total insulin doses administered through two major Kenyan hospitals in $2019 .{ }^{20}$ The authors suggest that such widespread use is predominantly due to affordability. In contrast, some evidence from Bangladesh suggests that long-acting insulin is more widely used amongst adults, perhaps due to the greater availability of biosimilars. ${ }^{21}$ Although procurement patterns in Kenya may result in physician 
familiarity with this product, Novo Nordisk could play a more active role in promoting other types of insulin that are more suitable for children and adolescents through staff training within the CDiC scheme. More regular training of healthcare workers is also needed to maintain high levels of specialised knowledge on paediatric care, particularly given system-level health workforce challenges in Kenya and Bangladesh. There are opportunities to produce online training videos and guidelines that can be shown to new staff working within the program, and that could also be shared with staff nationwide at relatively low cost.

Additionally, patients in Kenya felt they were given too little support in managing the transition to adulthood and the cessation of the free insulin supply. According to respondents, the only option available to patients aging out of the program was to have them enrol with the National Hospital Insurance Fund (NHIF). However, in the devolved Kenyan health system, although in some counties insulin is covered by NHIF, many counties reported poor and unreliable NHIF funding for Diabetes care and supplies, including insulin. Additionally, insurance cost around 500 KES per month, an unaffordable amount for many Kenyans. This is perhaps reflected in the relatively low insurance coverage observed, of around $15 \%{ }^{22}$ Although the authors were unable to provide separate estimates for Type 1 and Type 2 diabetes, one study in Kenya estimated median annual direct patient costs for diabetes of KES $53906(\sim 530) .{ }^{23}$ This is clearly concerning in a country with a poverty rate of $36.1 \% .{ }^{24}$

Indirect costs of care can also be significant. In Kenya, many children lived long distances from clinics, resulting in journeys of up to $300 \mathrm{~km}$ at a cost of up to 500 KES ( $\$ 5$ USD) per person. In Bangladesh, geographic inaccessibility across the country was a strong concern. With only three CDiC centres nationally, many T1DM children do not receive adequate treatment. It is estimated that around half of T1DM children in Bangladesh do not access regular services and that around 200 regular patients at Dhaka CDiC ( 10\%) come from the Northwest of the country, which is a day's bus journey. The costs of transport as well as the actual costs of treatment were highlighted by many as a weakness of the scheme. This, together with difficulties with geographic access, may partly explain the relatively high drop-out rate from the program $(\sim 25 \%)$. To avoid this, wherever possible, insulin should be available through smaller facilities closer to where children live, such as pharmacies, in order to reduce the number of required visits to diabetes clinics at larger hospitals.

The sustainability of the project was another important concern emerging from the analysis in both countries. In Kenya, facilities expressed concern that any transition away from donor support would be extremely difficult to navigate. Facilities and counties included in the study had significantly varying capacity to manage any such transition. In the devolved Kenyan health system, the capacity of counties to fund the scheme, as well as the capacity of healthcare professionals to lobby for such changes, varied considerably. In Bangladesh, stakeholders suggested that in the long-term, the government must be responsible for providing insulin to children. An extension of CDiC in 2017 with reduced funding has meant staff cuts and additional costs to patients. Patients still receive free insulin but frequently have to pay for glucometer strips, consultation fees, lab costs, transport costs and syringes. Importantly, it appears that the increase in patient costs was not communicated in advance and came as a shock to patients, families and staff. BADAS, through its social welfare division, does help to subsidise fees. Although the plans for long-term transitions are currently uncertain, established working relationships will be key in facilitating long-term government support and funding for the program. Additionally, increasing the level of peer support available to children, such as through involving Diabetes support groups, will help to empower diabetic children and their carers to be able to defend their interests. Strengthening patient advocacy in each country will help to promote increased access to care in the absence of external funding. In Bangladesh, the government plans to introduce free provision of insulin to all type 1 diabetics in the near future. ${ }^{25}$

One possible barrier to obtaining scarce government funds is the perceived small scale of the T1DM disease burden in children, compared to other diseases. Much of the burden of disease is hidden, as children remain undiagnosed, fail to receive treatment and eventually die. Although awareness has improved recently, with an increase in the number of campaigns relating to NCDs, it remains low compared to awareness of communicable diseases. Effective communication of the hidden burden of 
disease, as well as the impact of the CDiC program and provision of insulin on children's lives, should help to build government support and local ownership of the program over time.

As outlined above, the long-term sustainability of $\mathrm{CDiC}$ is uncertain. Of course, sustainable and affordable provision of insulin globally is hindered by high costs as a result of limited competition in insulin markets and a lack of biosimilar manufacturers. ${ }^{26-28}$ The addition of insulin to the WHO Prequalification Programme should in future facilitate market entry and therefore improve insulin access globally. ${ }^{29,30}$ Although addressing these issues is largely beyond the scope of the current article, in our view, the only sustainable way insulin can be provided permanently is through universal access under a national health insurance program. However, in the context of LMICs, expanded insulin coverage through increased general taxation may not be feasible. Improving access to insulin also presents unique challenges for more innovative financing mechanisms. Whereas such approaches typically focus on innovation or adoption of new health technologies, insulin is a well-established treatment with proven efficacy and a unique market structure. Alternative funding mechanisms to improve insulin access in LMICs, include taxes on soft drinks, taxes on international transactions, trademark-based revenue generation approaches and social impact bonds. ${ }^{31}$ However, Novo Nordisk must work with national governments to develop a clear long-term plan for transitioning to sustainable insulin provision. Although $\mathrm{CDiC}$ have attempted to involve local stakeholders from the outset, this transition will require very active support throughout a gradual phasing out of the program. An article outlines in detail ten steps that donors and governments should take together to phase out donor support, ranging from detailed program knowledge transfer in the early stages, to eventual donor creation of intra-country differential insulin pricing mechanisms to ensure affordability of insulin. ${ }^{32}$

We also acknowledge a few limitations to our study. We were unable to measure clinical outcomes, such as $\mathrm{HbA1C}$ levels, as existing data were limited and we were unable to collect samples as part of our study design. By interviewing only patients who are able to access care, we did not collect data from patients with Diabetes who are unable to access care. Additionally, we only interviewed children currently enrolled in the program and were unable to interview anyone who had transitioned to adult care, or who had dropped out of the program. Those who have successfully transitioned to adult care and disease management may have been able to provide valuable advice and insight for both staff and other children on how best to manage the transition. Due to budget and timescales, it was not possible to evaluate all of the facilities implementing CDiC in Kenya. To mitigate this limitation, facilities were chosen to ensure a representative sample on the basis of demographic, economic and geographic characteristics. Although "control" facilities provide some insight into usual care we were unable to visit a large range of non-CDiC facilities due to time and resource constraints. Additionally, in Bangladesh, comparisons with the "control" facility are more limited due to high national coverage of both CDiC and LFAC. Finally, the CDiC program was established in 2009 in Bangladesh and in 2012 in Kenya. An earlier evaluation embedded in project planning may have been preferable, as it may have provided greater understanding of the impact of the project and better-informed project expansion.

\section{Conclusion}

As the burden of NCDs such as Diabetes continues to rise in LMICs, health systems will be increasingly strained. The most vulnerable patients, including children and the poorest families, risk being excluded from care. The $\mathrm{CDiC}$ scheme has been successful in providing a stable supply of free insulin to children in implementing facilities in Kenya and Bangladesh and offers a comprehensive package of paediatric diabetes care. Prior to $\mathrm{CDiC}$, tailored paediatric care for Diabetes was lacking in both contexts. By providing insulin to children who may otherwise be unable to either access or afford it, it is clear that $\mathrm{CDiC}$ continues to reduce preventable deaths from Diabetes among some of the world's most vulnerable children. However, the program has some important limitations, including a lack of support for young people graduating from the program into adult care. Additionally, despite free insulin, overall costs of care remain too high for many families in Kenya and Bangladesh. 
Public-private partnerships such as the $\mathrm{CDiC}$ program, can significantly improve access to life-saving medicines as shown in this study. However, any program reliant on external funding sources and delivered in a high-turnover staffing environment, will be vulnerable to questions about sustainability. Perhaps as a direct result of its success, local stakeholders are anxious for the $\mathrm{CDiC}$ program to continue. To maintain the positive benefits of the $\mathrm{CDiC}$ achieved to date, and achieve long-term sustainable provision of insulin, innovative reinforcement and transition techniques may be needed.

\section{References}

1. Saeedi P, Petersohn I, Salpea P, et al. Global and regional diabetes prevalence estimates for 2019 and projections for 2030 and 2045: Results from the International Diabetes Federation Diabetes Atlas. Diabetes Res Clin Pract. 2019;157:107843. doi:10.1016/j.diabres.2019.107843

2. Atun R, Davies JI, Gale EAM, et al. Diabetes in sub-Saharan Africa: from clinical care to health policy. Lancet Diabetes Endocrinol. 2017;5(8):622-667. doi:10.1016/S2213-8587(17)30181-X

3. Muze KC, Majaliwa ES. Type 1 diabetes care updates: Tanzania. Indian J Endocrinol Metab. 2015;19(Suppl 1):S12-13. doi:10.4103/2230-8210.155348

4. Pacaud D, Lemay J-F, Richmond E, et al. Contribution of SWEET to improve paediatric diabetes care in developing countries. Pediatr Diabetes. 2016;17 Suppl 23:46-52. doi:10.1111/pedi.12427

5. Kalyva E, Malakonaki E, Eiser C, Mamoulakis D. Health-related quality of life (HRQoL) of children with type 1 diabetes mellitus (T1DM): self and parental perceptions. Pediatr Diabetes. 2011;12(1):34-40. doi:10.1111/j.1399-5448.2010.00653.x

6. Diabetes Control and Complications Trial Research Group. The effect of intensive treatment of diabetes on the development and progression of long-term complications in insulin-dependent diabetes mellitus. N Engl J Med. 1993;329(14):977-986. doi:10.1056/NEJM199309303291401.

7. Lontchi-Yimagou E, Mapa-Tassou C, Dehayem MY, et al. The effect of free diabetes care on metabolic control and on health-related quality of life among youths with type 1 diabetes in Cameroon. BMJ Open Diabetes Res Care. 2017;5(1).

8. Djonou C, Tankeu AT, Dehayem MY, Tcheutchoua DN, Mbanya JC, Sobngwi E. Glycemic control and correlates in a group of sub Saharan type 1 diabetes adolescents. BMC Res Notes. 2019;12(1):50. doi:10.1186/s13104-019-4054-1

9. Zabeen B, Banerjee B, Tayyeb S, et al. Comparative evaluation of glycemic control in children and adolescents with diabetes after the implementation of self-monitoring tests distributed through CDiC program in Bangladesh [Abstract P99]. In: Vol 14(suppl 18). Pediatric Diabetes; 2013:88.

10. Ngwiri T, Were F, Predieri B, Ngugi P, Iughetti L. Glycemic control in Kenyan children and adolescents with type 1 diabetes mellitus. Int J Endocrinol. 2015;2015. doi:10.1155/2015/761759

11. Petitti DB, Klingensmith GJ, Bell RA, et al. Glycemic Control in Youth with Diabetes: The SEARCH for Diabetes in Youth Study. J Pediatr. 2009;155(5):668-672.e3. doi:10.1016/j.jpeds.2009.05.025 
12. Pihoker C, Forsander G, Fantahun B, et al. ISPAD Clinical Practice Consensus Guidelines 2018: The delivery of ambulatory diabetes care to children and adolescents with diabetes. Pediatr Diabetes. 2018;19:84-104.

13. Diabetic Association of Bangladesh. Accessed January 29, 2021. https://www.dab-bd.org/subpage.php?sub_category $=40$

14. Kaufman F. Treating T1D in Bangladesh: Dr. Kaufman + Life for a Child. Beyond Type 1. Published October 25, 2019. Accessed January 29, 2021. https://beyondtype1.org/t1d-inbangladesh/

15. Beran D, Yudkin JS, de Courten M. Assessing health systems for type 1 diabetes in sub-Saharan Africa: developing a'Rapid Assessment Protocol for Insulin Access'. BMC Health Serv Res. 2006;6(1):1-9.

16. Shannon GD, Haghparast-Bidgoli H, Chelagat W, Kibachio J, Skordis-Worrall J. Innovating to increase access to diabetes care in Kenya: an evaluation of Novo Nordisk's base of the pyramid project. Glob Health Action. 2019;12(1):1605704. doi:10.1080/16549716.2019.1605704

17. Palmer T, Waliaula C, Shannon G, et al. Understanding the lived experience of children with type 1 diabetes in Kenya: using photo diaries to extend qualitative insights. Published online 2021.

18. Danne T, Phillip M, Buckingham BA, et al. ISPAD Clinical Practice Consensus Guidelines 2018: Insulin treatment in children and adolescents with diabetes. Pediatr Diabetes. 2018;19(S27):115135. doi:https://doi.org/10.1111/pedi.12718

19. Mortensen HB, Robertson KJ, Aanstoot HJ, et al. Insulin management and metabolic control of type 1 diabetes mellitus in childhood and adolescence in 18 countries. Hvidøre Study Group on Childhood Diabetes. Diabet Med J Br Diabet Assoc. 1998;15(9):752-759. doi:10.1002/(SICI)1096-9136(199809)15:9<752::AID-DIA678>3.0.CO;2-W

20. Opanga S, Njeri LW, Kimonge D, Godman B, Oluka M. Assessing utilisation and expenditure on long-acting insulin analogues in Kenya; findings and implications for the future. Sch Acad J Pharm. 2021;10(4):63-70.

21. Haque M, Islam S, Kamal ZM, et al. Ongoing efforts to improve the management of patients with diabetes in Bangladesh and the implications. Hosp Pract. 2021;0(0):1-7. doi:10.1080/21548331.2021.1906083

22. Barasa E, Rogo K, Mwaura N, Chuma J. Kenya National Hospital Insurance Fund Reforms: implications and lessons for universal health coverage. Health Syst Reform. 2018;4(4):346-361.

23. Oyando R, Njoroge M, Nguhiu P, et al. Patient costs of diabetes mellitus care in public health care facilities in Kenya. Int J Health Plann Manage. 2020;35(1):290-308. doi:10.1002/hpm.2905

24. Kenya National Bureau of Statistics. Basic Report on Well-Being in Kenya.; 2018. Accessed May 6, 2021. http://www.knbs.or.ke/?wpdmpro=basic-report-well-kenya-based-201516-kenyaintegrated-household-budget-survey-kihbs

25. Atapattu N, Mohsin F, Zabeen B, Seneviratne SN. Pediatric diabetes care in Sri Lanka and Bangladesh: Reaching the community. Pediatr Diabetes. 2021;22(1):112-115. doi:10.1111/pedi.13102

26. Beran D, Ewen M, Laing R. Constraints and challenges in access to insulin: a global perspective. Lancet Diabetes Endocrinol. 2016;4(3):275-285. doi:10.1016/S2213-8587(15)00521-5 
27. Perrin C, Ewen M, Beran D. The role of biosimilar manufacturers in improving access to insulin globally. Lancet Diabetes Endocrinol. 2017;5(8):578. doi:10.1016/S2213-8587(17)30218-8

28. McCall C. Biosimilars for insulin: a cost-saving alternative? Lancet Lond Engl. 2018;392(10146):463-464.

29. Beran D, Lazo-Porras M, Mba CM, Mbanya JC. A global perspective on the issue of access to insulin. Diabetologia. Published online 2021:1-9.

30. World Health Organization. WHO launches first-ever insulin prequalification programme to expand access to life-saving treatment for diabetes. Published 2019. Accessed May 6, 2021. https://www.who.int/news/item/13-11-2019-who-launches-first-ever-insulin-prequalificationprogramme-to-expand-access-to-life-saving-treatment-for-diabetes

31. Luo J. Alternative Funding Sources to Improve Insulin Access: A Briefing Document for Low-and Middle-Income Countries.; 2018. Accessed May 6, 2021. https://accisstoolkit.haiweb.org/wpcontent/uploads/2020/10/Alternative_Funding_Sources_to_Improve_Insulin_Access.pdf

32. Hogerzeil HV, Recourt S. The importance of insulin donations for children in 43 low- and middle-income countries. J Public Health Policy. 2019;40(2):253-263. doi:10.1057/s41271-01800159-w 


\section{Figures and Tables}

\section{Main text}

Table 1

Table 1a: Summary of facility- and county-level characteristics for included facilities - Kenya

\begin{tabular}{|c|c|c|c|c|c|c|c|c|}
\hline \multirow[t]{2}{*}{ Facility } & \multicolumn{2}{|c|}{$\begin{array}{l}\text { Facility } \\
\text { characteristics }\end{array}$} & \multicolumn{6}{|c|}{ County characteristics } \\
\hline & Beds $^{1}$ & $\operatorname{Cots}^{1}$ & $\begin{array}{l}\text { County } \\
\text { total } \\
\text { population } \\
\text { (2019) }\end{array}$ & $\begin{array}{l}\text { Urban } \\
\text { population } \\
\text { (2019) }\end{array}$ & $\begin{array}{l}\text { Health } \\
\text { facilities } \\
1 \\
(2015)\end{array}$ & $\begin{array}{l}\text { Births } \\
\text { delivered at } \\
\text { health } \\
\text { facility }^{3} \\
(2014)\end{array}$ & $\begin{array}{l}\text { Povert } \\
\text { y } \\
\text { headc } \\
\text { ount } \\
\text { rate } \\
(2015) \\
4\end{array}$ & $\begin{array}{l}\text { Average } \\
\text { morbidity } \\
(2016)^{5}\end{array}$ \\
\hline $\begin{array}{l}\text { Embu } \\
\text { County } \\
\text { Referral } \\
\text { Hospital }\end{array}$ & 618 & 97 & 608,599 & $12.48 \%$ & 172 & $82 \%$ & $28.3 \%$ & $19.5 \%$ \\
\hline $\begin{array}{l}\text { Chuka } \\
\text { Referral } \\
\text { Hospital }\end{array}$ & 85 & 2 & 393,177 & $8.33 \%$ & 127 & $78 \%$ & $31.2 \%$ & $22.1 \%$ \\
\hline $\begin{array}{l}\text { Kisii } \\
\text { County } \\
\text { Referral } \\
\text { Hospital }\end{array}$ & 379 & 20 & $1,266,860$ & $11.95 \%$ & 161 & $69 \%$ & $44.5 \%$ & $23.8 \%$ \\
\hline $\begin{array}{l}\text { Ngaira } \\
\text { Dispensa } \\
\text { ry } \\
\text { (Nairobi } \\
\text { County) }\end{array}$ & 0 & 0 & $4,397,073$ & $100 \%$ & 915 & $89 \%$ & $16.1 \%$ & $25.3 \%$ \\
\hline $\begin{array}{l}\text { Nakuru } \\
\text { County } \\
\text { Referral } \\
\text { Hospital }\end{array}$ & 588 & 68 & $2,162,202$ & $48.4 \%$ & 423 & $70 \%$ & $19.6 \%$ & $19.1 \%$ \\
\hline $\begin{array}{l}\text { Kericho } \\
\text { County } \\
\text { Referral } \\
\text { Hospital }\end{array}$ & 250 & 20 & 901,777 & $10.4 \%$ & 198 & $62 \%$ & $31.4 \%$ & $17.8 \%$ \\
\hline $\begin{array}{l}\text { Kitale } \\
\text { County } \\
\text { Referral } \\
\text { Hospital } \\
\text { (Control) }\end{array}$ & 250 & 12 & 990,341 & $18.0 \%$ & 151 & $42 \%$ & $33.3 \%$ & $32.5 \%$ \\
\hline $\begin{array}{l}\text { County- } \\
\text { level } \\
\text { mean }\end{array}$ & - & - & $1,012,007$ & $23.0 \%$ & 213 & $57.1 \%$ & $35.4 \%$ & $26.1 \%$ \\
\hline $\begin{array}{l}\text { KENYA } \\
\text { TOTAL }\end{array}$ & - & - & $47,564,316$ & $31.1 \%$ & 9,989 & $61.2 \%$ & $36.1 \%$ & \\
\hline
\end{tabular}


Sources: ${ }^{1}$ Kenya Ministry of Health; ${ }^{2} 2019$ Kenya Population and Housing Survey; ${ }^{3}$ Kenya Demographic Health Survey (DHS); ${ }^{4}$ Kenya Integrated Household Budget Survey (KIHBS); ${ }^{5}$ Kenya Open Data. Each variable reported for the most recent year in which data is available.

Table 1b: Summary of facility- and district-level characteristics for included facilities - Bangladesh

\begin{tabular}{|c|c|c|c|c|c|c|c|c|}
\hline \multirow[t]{2}{*}{ Place } & \multicolumn{2}{|c|}{$\begin{array}{l}\text { Facility } \\
\text { characteristics }\end{array}$} & \multicolumn{2}{|c|}{ Division characteristics } & \multicolumn{4}{|c|}{ District characteristics } \\
\hline & Beds & $\begin{array}{l}\text { Daily } \\
\text { outpatien } \\
\text { ts }\end{array}$ & $\begin{array}{l}\text { Population } \\
1 \\
(2011)\end{array}$ & $\begin{array}{l}\text { Number of } \\
\text { health } \\
\text { facilities }^{2} \\
(2011)\end{array}$ & $\begin{array}{l}\text { District } \\
\text { Population } \\
1 \\
(2011)\end{array}$ & $\begin{array}{l}\text { City } \\
\text { population } \\
1 \\
(2011)\end{array}$ & $\begin{array}{l}\text { Literacy }^{3} \\
(2016)\end{array}$ & $\begin{array}{l}\text { Poverty } \\
\text { headcount } \\
\text { rate }^{3} \\
(2016)\end{array}$ \\
\hline Dhaka & 200 & $\begin{array}{l}1000- \\
1500\end{array}$ & $36,433,505$ & 3,947 & $12,043,977$ & $6,970,105$ & $73 \%$ & $16 \%$ \\
\hline $\begin{array}{l}\text { Faridpur } \\
\text { (Dhaka } \\
\text { division) }\end{array}$ & 400 & $\begin{array}{l}1500- \\
2000\end{array}$ & & & $1,912,969$ & 179,037 & $47 \%$ & $36 \%$ \\
\hline $\begin{array}{l}\text { Gazipur } \\
\text { (Dhaka } \\
\text { division) } \\
\end{array}$ & 60 & $100-150$ & & & $3,404,912$ & 121,632 & $64 \%$ & $19 \%$ \\
\hline Chittagong & 250 & 200 & $28,423,019$ & 3,747 & $7,616,352$ & $2,582,401$ & $61 \%$ & $12 \%$ \\
\hline $\begin{array}{l}\text { Bangladesh } \\
\text { total }\end{array}$ & & & $\begin{array}{l}144,043,69 \\
7\end{array}$ & 19,811 & & & $72 \%$ & $24 \%$ \\
\hline
\end{tabular}

Sources: ${ }^{1}$ Bangladesh Population Census (2011); ${ }^{2}$ National Institute of Population Research and Training (NIPORT) Ministry of Health and Family Welfare; Bangladesh Health Facility Survey $(2017) ;{ }^{3}$ World Bank (2020)

\section{Table 2}

Table 2: Overview of Micro, Meso and Macro (national/international) level interview

\begin{tabular}{|l|l|l|l|l|}
\hline \multicolumn{2}{|l|}{ KENYA (N=50) } & \multicolumn{2}{l|}{ BANGLADESH (N=75) } \\
\hline \multirow{2}{*}{ MICRO and MESO } & Facility staff & $7(6)$ & Facility staff & $9(9)$ \\
\cline { 2 - 6 } $\begin{array}{l}\text { Intervention facilities } \\
\text { Number of participants } \\
\begin{array}{l}\text { (number of } \\
\text { interviews/focus group } \\
\text { discussions) }\end{array}\end{array}$ Children & $13(3)$ & Children & $50(10)$ \\
\cline { 2 - 6 } & Carers & $10(3)$ & Carers & 5 \\
\cline { 2 - 6 } & Total & $30(12)$ & Total & $64(24)$ \\
\hline \multirow{2}{*}{$\begin{array}{l}\text { Control facilities } \\
\text { Number of participants } \\
\text { (number of } \\
\text { interviews/focus group } \\
\text { discussions) }\end{array}$} & Facility staff & $2(2)$ & Facility staff & $4(4)$ \\
\cline { 2 - 6 } & Children & $2(1)$ & Children & 0 \\
\cline { 2 - 6 } & Carers & $4(2)$ & Carers & 0 \\
\hline
\end{tabular}




\begin{tabular}{|c|c|c|c|c|}
\hline & Total & $8(5)$ & Total & $4(4)$ \\
\hline \multicolumn{5}{|l|}{ MACRO (national) } \\
\hline \multirow{8}{*}{$\begin{array}{l}\text { Number of participants } \\
\text { by organisation } \\
\text { (number of } \\
\text { interviews/focus group } \\
\text { discussions) }\end{array}$} & Novo Nordisk & $3(2)$ & Novo Nordisk & $2(2)$ \\
\hline & $\begin{array}{l}\text { Kenya Defeat } \\
\text { Diabetes } \\
\text { Association }\end{array}$ & $2(1)$ & Ministry of Health & $1(1)$ \\
\hline & $\begin{array}{l}\text { Kenya Medical } \\
\text { Supplies Agency }\end{array}$ & $1(1)$ & $\begin{array}{l}\text { Bangladesh } \\
\text { Diabetes } \\
\text { Association }\end{array}$ & $2(2)$ \\
\hline & $\begin{array}{l}\text { Ministry of } \\
\text { Health }\end{array}$ & $2(2)$ & $\begin{array}{l}\text { Centre for NCDs, } \\
\text { ICDDR,B }\end{array}$ & $1(1)$ \\
\hline & $\begin{array}{l}\text { Kenya Diabetes } \\
\text { Management \& } \\
\text { Information } \\
\text { Centre }\end{array}$ & $2(1)$ & Life for a Child & $1(1)$ \\
\hline & Roche & $1(1)$ & & \\
\hline & $\begin{array}{l}\text { Pediatric } \\
\text { Endocrinology } \\
\text { Training Centre } \\
\text { for Africa }\end{array}$ & $1(1)$ & & \\
\hline & Total & $12(9)$ & Total & $7(7)$ \\
\hline \multicolumn{5}{|l|}{ MACRO (international) } \\
\hline \multirow{2}{*}{$\begin{array}{l}\text { Number of participants } \\
\text { by organisation } \\
\text { (number of } \\
\text { interviews/focus group } \\
\text { discussions) }\end{array}$} & \multicolumn{2}{|c|}{$\begin{array}{l}\text { International Society for Pediatric } \\
\text { and Adolescent Diabetes }\end{array}$} & \multicolumn{2}{|l|}{$1(1)$} \\
\hline & \multicolumn{2}{|c|}{ World Diabetes Foundation } & \multicolumn{2}{|l|}{$1(1)$} \\
\hline
\end{tabular}




\section{Appendix}

Table A1: CDiC Evaluation: Adaptation of the RAPIA approach

\begin{tabular}{|c|c|c|}
\hline Stakeholder & RAPIA Interview Themes & Research Questions \\
\hline \multicolumn{3}{|c|}{ MACRO (INTERNATIONAL) LEVEL INTERVIEWS } \\
\hline Novo Nordisk & $\begin{array}{l}\text { - Distribution of insulin } \\
\text { - Insulin tendering and purchase } \\
\text { - Value share to Novo Nordisk } \\
\text { - Perceptions of CDiC acceptability, } \\
\text { effectiveness and sustainability } \\
\text { - Stakeholder engagement in CDiC } \\
\text { - Institutional support for sustained and up- } \\
\text { scaled CDiC activities }\end{array}$ & $\begin{array}{l}\text { - Does CDiC improve the infrastructure for Diabetes } \\
\text { care for children with Diabetes? } \\
\text { - Has CDiC facilitated training and education of } \\
\text { healthcare professionals? } \\
\text { - Has CDiC improved the provision of insulin and blood } \\
\text { glucose monitoring equipment? } \\
\text { - Has CDiC improved the provision of patient education } \\
\text { materials? } \\
\text { - Have patient registration and effective data } \\
\text { management practices been established? }\end{array}$ \\
\hline Roche & $\begin{array}{l}\text { - Distribution of glucometers and equipment } \\
\text { - Vor monitoring Diabetes care } \\
\text { - Awareness of CDiC } \\
\text { - Perceptions of CDiC acceptability, } \\
\text { effectiveness and sustainability } \\
\text { - Stakeholder engagement in CDiC } \\
\text { - Institutional support for sustained and up- } \\
\text { scaled CDiC activities }\end{array}$ & $\begin{array}{l}\text { - Does } \mathrm{CDiC} \text { improve the infrastructure for Diabetes } \\
\text { care for children with Diabetes? } \\
\text { - Has CDiC facilitated training and education of } \\
\text { healthcare professionals? } \\
\text { - Has } \mathrm{CDiC} \text { improved the provision of insulin and blood } \\
\text { glucose monitoring equipment? } \\
\text { - Has CDiC improved the provision of patient education } \\
\text { materials? } \\
\text { - Have patient registration and effective data } \\
\text { management practices been established? }\end{array}$ \\
\hline $\begin{array}{l}\text { International } \\
\text { Society for } \\
\text { aediatric and } \\
\text { Adolescent } \\
\text { Diabetes }\end{array}$ & $\begin{array}{l}\text { - Role of organization in Diabetes care, } \\
\text { education, training } \\
\text { - Awareness of CDiC } \\
\text { - Perceptions of CDiC acceptability, } \\
\text { effectiveness and sustainability } \\
\text { - Stakeholder engagement in CDiC } \\
\text { - Institutional support for sustained and up- } \\
\text { scaled CDiC activities }\end{array}$ & $\begin{array}{l}\text { - Does CDiC improve the infrastructure for Diabetes } \\
\text { care for children with Diabetes? } \\
\text { - Has CDiC facilitated training and education of } \\
\text { healthcare professionals? } \\
\text { - Has CDiC improved the provision of patient education } \\
\text { material? }\end{array}$ \\
\hline $\begin{array}{l}\text { World Diabete } \\
\text { Foundation }\end{array}$ & $\begin{array}{l}\text { - Role of organization in Diabetes care, } \\
\text { education, training, advocacy } \\
\text { - Awareness of CDiC } \\
\text { - Perceptions of CDiC acceptability, } \\
\text { - effectiveness and sustainability } \\
\text { - Stakeholder engagement in CDiC } \\
\text { - Institutional support for sustained and up- } \\
\text { scaled CDiC activities }\end{array}$ & $\begin{array}{l}\text { - Does } \mathrm{CDiC} \text { improve the infrastructure for Diabetes } \\
\text { care for children with Diabetes? } \\
\text { - Has CDiC facilitated training and education of } \\
\text { healthcare professionals? } \\
\text { - Has } \mathrm{CDiC} \text { improved the provision of insulin and blood } \\
\text { glucose monitoring equipment? } \\
\text { - Has CDiC improved the provision of patient education } \\
\text { material? }\end{array}$ \\
\hline \multicolumn{3}{|c|}{ MESO (NATIONAL/HEALTHCARE SERVICE) LEVEL INTERVIEWS } \\
\hline $\begin{array}{l}\text { National Ministry } \\
\text { of Health } \\
\text { (Bangladesh, } \\
\text { Kenya) }\end{array}$ & $\begin{array}{l}\text { - Role of organization in Diabetes healthcare } \\
\text { systems/management } \\
\text { - Awareness of CDiC } \\
\text { - Perceptions of CDiC acceptability, }\end{array}$ & $\begin{array}{l}\text { - Does } \mathrm{CDiC} \text { improve existing infrastructure for } \\
\text { Diabetes care for children with Diabetes? }\end{array}$ \\
\hline
\end{tabular}




\begin{tabular}{|c|c|c|}
\hline & $\begin{array}{l}\text { effectiveness and sustainability } \\
\text { - Stakeholder engagement in CDiC } \\
\text { scaled CDiC activities }\end{array}$ & $\begin{array}{l}\text { - Has CDiC facilitated training and education of } \\
\text { healthcare professionals? } \\
\text { - Has } \mathrm{CDiC} \text { improved the provision of insulin and blood } \\
\text { glucose monitoring equipment? } \\
\text { - Has CDiC improved the provision of patient education } \\
\text { material? } \\
\text { - Have patient registration and effective data } \\
\text { management practices been established? } \\
\text { - Is best practice sharing occurring? }\end{array}$ \\
\hline $\begin{array}{l}\text { National partners } \\
\text { (Bangladesh, } \\
\text { Kenya) }\end{array}$ & $\begin{array}{l}\text { - Role of organization in Diabetes care } \\
\text { - Awareness of CDiC } \\
\text { - Perceptions of CDiC acceptability, } \\
\text { - Stakectiveness and sustainability } \\
\text { - Institutional support for sustained and up- } \\
\text { scaled CDiC activities }\end{array}$ & $\begin{array}{l}\text { - Does } \mathrm{CDiC} \text { improve existing infrastructure for } \\
\text { Diabetes care for children with Diabetes? } \\
\text { - Has CDiC facilitated training and education of } \\
\text { - healthcare professionals? } \\
\text { - Has CDiC improved the provision of insulin and blood } \\
\text { glucose monitoring equipment? } \\
\text { - Has CDiC improved the provision of patient education } \\
\text { material? } \\
\text { - Have patient registration and effective data } \\
\text { management practices been established? }\end{array}$ \\
\hline $\begin{array}{l}\text { Healthcare } \\
\text { Facilities }\end{array}$ & $\begin{array}{l}\text { - Role of organization in Diabetes care } \\
\text { - Awareness of CDiC } \\
\text { - Perceptions of CDiC acceptability, } \\
\text { - Sffectiveness and sustainability } \\
\text { - Institutional support for sustained and up- } \\
\text { scaled CDiC activities }\end{array}$ & $\begin{array}{l}\text { - Does CDiC improve the infrastructure for Diabetes } \\
\text { care for children with Diabetes? } \\
\text { - Has CDiC facilitated training and education of } \\
\text { healthcare professionals? } \\
\text { - Has CDiC improved the provision of insulin and blood } \\
\text { glucose monitoring equipment? } \\
\text { - Has CDiC improved the provision of patient education } \\
\text { material? } \\
\text { - Have patient registration and effective data } \\
\text { management practices been established? } \\
\text { - Is best practice sharing occurring? } \\
\text { Diabetes? }\end{array}$ \\
\hline \multicolumn{3}{|c|}{ MICRO (HEALTH FACILITY AND INDIVIDUAL) LEVEL INTERVIEWS } \\
\hline Health Workers & $\begin{array}{l}\text { - Problems encountered in diagnosis and } \\
\text { - Treatment of patients } \\
\text { - Infrastructure present and/or lacking } \\
\text { - Tools present and/or lacking } \\
\text { - Awareness of CDiC } \\
\text { - Perceptions of CDiC acceptability, } \\
\text { effectiveness and sustainability }\end{array}$ & $\begin{array}{l}\text { - What barriers to care exist for patients with Type } 1 \\
\text { Diabetes? } \\
\text { - Has CDiC improved access to Diabetes care? } \\
\text { - Has CDiC facilitated training and education of } \\
\text { healthcare professionals? } \\
\text { - Has CDiC improved the provision of insulin and blood } \\
\text { glucose monitoring equipment? } \\
\text { - Has CDiC improved the provision of patient education } \\
\text { material? }\end{array}$ \\
\hline $\begin{array}{l}\text { Community } \\
\text { Health } \\
\text { Volunteers }\end{array}$ & $\begin{array}{l}\text { - Awareness of Diabetes and Insulin } \\
\text { - Access to insulin for resale } \\
\text { - Pricing of insulin } \\
\text { - Awareness of CDiC } \\
\text { - Perceptions of CDiC acceptability } \\
\text { effectiveness and sustainability }\end{array}$ & $\begin{array}{l}\text { - What barriers to care exist for patients with Type } 1 \\
\text { Diabetes? } \\
\text { - Has } \mathrm{CDiC} \text { improved access to Diabetes care? } \\
\text { - Has CDiC facilitated training and education of } \\
\text { healthcare professionals? } \\
\text { - Has CDiC improved the provision of insulin and blood } \\
\text { glucose monitoring equipment? } \\
\text { - Has CDiC improved the provision of patient education } \\
\text { material? }\end{array}$ \\
\hline
\end{tabular}




\begin{tabular}{|c|c|c|}
\hline $\begin{array}{l}\text { Patients } \\
\text { Carers }\end{array}$ & $\begin{array}{l}\text { - Diagnosis } \\
\text { - Access to treatment } \\
\text { and } \text { Cost of treatment } \\
\text { - Awareness of Diabetes } \\
\text { - Awareness of CDiC } \\
\text { - Perceptions of CDiC acceptability, } \\
\text { effectiveness and sustainability }\end{array}$ & $\begin{array}{l}\text { - What barriers to care exist for patients with Type } 1 \\
\text { Diabetes? } \\
\text { - Has } \mathrm{CDiC} \text { improved access to Diabetes care? } \\
\text { - Has } \mathrm{CDiC} \text { improved the provision of insulin and blood } \\
\text { glucose monitoring equipment? } \\
\text { - Has CDiC improved the provision of patient education } \\
\text { material? }\end{array}$ \\
\hline
\end{tabular}

Table A2: CDiC Evaluation: Summary of included facilities

Table A2.1 Kenya

\begin{tabular}{|l|l|l|l|l|l|}
\hline Facility & $\begin{array}{l}\text { Facility visit } \\
\text { and audit }\end{array}$ & $\begin{array}{l}\text { FGD with } \\
\text { parents }\end{array}$ & $\begin{array}{l}\text { FGD with } \\
\text { children }\end{array}$ & Photo-diary & $\begin{array}{l}\text { Interviews } \\
\text { with staff }\end{array}$ \\
\hline $\begin{array}{l}\text { Embu County Referral } \\
\text { Hospital }\end{array}$ & $\boldsymbol{x}$ & $\boldsymbol{x}$ & $\boldsymbol{x}$ & $\boldsymbol{x}$ & $\checkmark$ \\
\hline Chuka Referral Hospital & $\checkmark$ & $\boldsymbol{x}$ & $\boldsymbol{x}$ & $\boldsymbol{x}$ & $\checkmark$ \\
\hline $\begin{array}{l}\text { Kisii County Referral } \\
\text { Hospital }\end{array}$ & $\checkmark$ & $\checkmark$ & $\checkmark$ & $\checkmark$ & $\checkmark$ \\
\hline $\begin{array}{l}\text { Ngaira Dispensary- } \\
\text { Nairobi County }\end{array}$ & $\checkmark$ & $\boldsymbol{x}$ & $\boldsymbol{\checkmark}$ & $\boldsymbol{\checkmark}$ & $\checkmark$ \\
\hline $\begin{array}{l}\text { Nakuru County Referral } \\
\text { Hospital }\end{array}$ & $\boldsymbol{x}$ & $\checkmark$ & $\checkmark$ & $\checkmark$ & $\checkmark$ \\
\hline $\begin{array}{l}\text { Kericho County Referral } \\
\text { Hospital }\end{array}$ & $\checkmark$ & $\checkmark$ & $\checkmark$ & $\checkmark$ & $\checkmark$ \\
\hline $\begin{array}{l}\text { Kitale County Referral } \\
\text { Hospital (CONTROL) }\end{array}$ & $\checkmark$ & & & & $\checkmark$ \\
\hline
\end{tabular}

Table A2.2 Bangladesh

\begin{tabular}{|l|l|l|l|l|l|}
\hline Facility & $\begin{array}{l}\text { Facility visit } \\
\text { and audit }\end{array}$ & $\begin{array}{l}\text { FGD with } \\
\text { parents }\end{array}$ & $\begin{array}{l}\text { FGD with } \\
\text { children }\end{array}$ & Photo-diary & $\begin{array}{l}\text { Interviews } \\
\text { with staff }\end{array}$ \\
\hline Dhaka & $\checkmark$ & $\checkmark$ & $\checkmark$ & $\checkmark$ & $\checkmark$ \\
\hline Chittagong & $\checkmark$ & $\checkmark$ & $\checkmark$ & $\checkmark$ & $\checkmark$ \\
\hline Faridpur & $\checkmark$ & $\checkmark$ & $\checkmark$ & $\checkmark$ & $\checkmark$ \\
\hline Gazipur (CONTROL) & $\checkmark$ & $x$ & $x$ & $x$ & $\checkmark$ \\
\hline
\end{tabular}

\section{References}

Kenya National Bureau of Statistics. Basic Report on Well-Being in Kenya.; 2018. Accessed May 6, 2021. http://www.knbs.or.ke/?wpdmpro=basic-report-well-kenya-based-201516-kenya-integratedhousehold-budget-survey-kihbs

Kenya National Bureau of Statistics. The 2019 Kenya Population and Housing Census. Volume 1. Kenya National Bureau of Statistics; 2019. Accessed May 6, 2021. http://www.knbs.or.ke/?wpdmpro=2019-kenya-population-and-housing-census-volume-i-populationby-county-and-sub-county 
Kenya National Bureau of Statistics. The 2019 Kenya Population and Housing Census. Volume 2.

Kenya National Bureau of Statistics; 2019. Accessed May 6, 2021. http://www.knbs.or.ke/?wpdmpro=2019-kenya-population-and-housing-census-volume-ii-

distribution-of-population-by-administrative-units

Kenya National Bureau of Statistics. Kenya Demographic and Health Survey, 2014.; 2017. Accessed May 6, 2021. http://www.knbs.or.ke/?wpdmpro=2014-kenya-demographic-and-health-survey

Kenya Open Data. 2020. Average morbidity in all genders 2016. Accessed 10 July, 2020.

https://opencounty.org/indicators.php?com=16\&source=Kenya\%20Open\%20Data

Ministry of Health K. Kenya Master Health Facility List Nairobi. Kenya: Ministry of Health, Kenya; 201. Accessed 10 July, 2020. http://kmhfl.health.go.ke/\#/home

National Institute of Population Research and Training (NIPORT) and ICF. 2019. Bangladesh Health Facility Survey 2017. Dhaka, Bangladesh: NIPORT, ACPR, and ICF. Accessed 6 May, 2021. https://dhsprogram.com/publications/publication-SPA28-SPA-Final-Reports.cfm

World Bank. 2020. Literacy rate, (\% of people ages 15 and above). Accessed 1 August, 2020. https://data.worldbank.org/indicator/SE.ADT.LITR.ZS

World Bank. 2020. Poverty Headcount ratio at national poverty lines (\% of population). Accessed 1 Aug, 2020. Available from https://data.worldbank.org/indicator/SI.POV.NAHC 